\title{
KAJIAN TINGKAT BAHAYA EROSI DAS MANNA
}

\author{
Irda Hayani $\mathrm{S}^{1)}$, M. Faiz Barchia ${ }^{2)}$, Edi Suharto ${ }^{3)}$. \\ 1) Program Studi Pascasarjana Pengelolaan Sumberdaya Alam dan Lingkungan, \\ Fakultas Pertanian Universitas Bengkulu \\ ${ }^{2)}$ Dosen Fakultas Pertanian Universitas Bengkulu \\ ${ }^{3)}$ Dosen Fakultas Pertanian Universitas Bengkulu
}

\begin{abstract}
ABSTRAK
Penelitian ini bertujuan untuk mengetahui kerusakan dan degradasi fungsi DAS Manna dengan pendekatan perhitungan tingkat bahaya erosi (TBE). Metoda yang digunakan dalam penelitian ini adalah metoda penelitian survei tinjau, yaitu dengan cara mengumpulkan data dan informasi serta fakta-fakta dari gejala di lapangan dan analisis data spasial peta tematik menggunakan Sistem Informasi Geografi (SIG), Penentuan tingkat erosi tanah dengan menggunakan metode USLE juga dilakukan fungsi-fungsi SIG yaitu tumpang susun seperti intersect. Hasil penelitian menunjukkan bahwa: sebagian besar wilayah DAS Manna berada pada kategori TBE sangat berat ( $>480$ ton/ha/th) yaitu seluas $46.204,5$ atau $64,1 \%$ dari total luasan DAS Manna, kategori Berat (180-480 ton/ha/th) seluas 10.399,8 Ha (14,4\%), kategori sedang (60-180 ton/ha/th) seluas $6.393,5 \mathrm{Ha}(8,9 \%)$ dan sangat rendah $(<15$ ton/ha/th) hanya seluas 1.533,2 Ha (2,1 \%). Hasil ini menunjukkan bahwa wilayah DAS Manna dapat digolongkan sebagai DAS yang kritis bila didasarkan pada potensi erosi yang mencapai lebih dari $64 \%$ dari total luasan DAS Manna. Sedangkan bila dianalisa pada tiap Sub DAS, maka Sub DAS Manna Hilir adalah Sub DAS yang memiliki TBE paling besar, yaitu sekitar 78,2 $\%(6.892,5 \mathrm{Ha})$ berada pada kategori Sangat Berat (>480 ton/ha/th) $6.892,5 \mathrm{Ha}$ atau 9,6\% dari total luasan DAS Manna, Berat (180-480 ton/ha/th) seluas 1.443,1 Ha atau $2 \%$ dari luas total luasan DAS Manna. Hasil tersebut sudah cukup menggambarkan bahwa DAS Manna dapat digolongkan kedalam DAS kritis berdasarkan potensi tingkat bahaya erosinya.
\end{abstract}

\section{Kata kunci:}

\section{PENDAHULUAN}

Daerah Aliran Sungai (DAS) sebagai suatu kesatuan bentang alam sangat penting perannya dalam melestarikan fungsi ekosistem. Kerusakan DAS dewasa ini dipercepat oleh peningkatan pemanfaatan sumberdaya alam sebagai akibat dari pertambahan penduduk dan perkembangan ekonomi, konflik kepentingan dan kurang keterpaduan antar sektor, antar wilayah hulu-tengah-hilir, terutama pada era otonomi dimana sumberdaya alam sering dipandang sebagai alat untuk meningkatkan pendapatan daerah.
Propinsi Bengkulu memiliki banyak satuan DAS yang perlu mendapat perhatian serius dari semua pihak, salah satunya adalah DAS DAS Manna karena kerusakannya cukup mengkhawatirkan. Kerusakan tersebut disebabkan oleh perambahan lahan di kawasan hutan produksi dan hutan lindung di daerah hulu. Munculnya aktivitas perambahan dan bentuk-bentuk perusakan hutan lainnya adalah karena kondisi sosial ekonomui masyarakat di sekitar hutan yang masih tergolong miskin.

Kerusakan lahan pada DAS Manna dapat mengakibatkan penurunan kesuburan dan daya dukung tanah. Pada tingkat 
lanjutan, kerusakan lahan dapat mengakibatkan bahaya banjir, erosi dan longsor pada musim hujan, serta penurunan debit air dan kurangnya air tanah pada musim kemarau.

Tingkat Bahaya Erosi (TBE). TBE merupakan salah satu variabel yang cukup efektif dalam menentukan status kerusakan dan degradasi suatu DAS. Penelitian ini ditujukan untuk mengetahui kerusakan dan degradasi fungsi DAS Manna dengan pendekatan perhitungan tingkat bahaya erosi (TBE). Hasil penelitian diharapkan dapat menjadi bahan infromasi dan acuan bagi stakeholder di wilayah DAS Manna dalam melestarikan ekosistem dan fungsi DAS Manna untuk kesejahteraan masyarakat dan pembangunan.

\section{METODA PENELITIAN}

\section{Lokasi dan waktu}

Penelitian dilaksanakan di DAS Manna yang terdiri atas 3 (tiga) sub DAS yaitu Manna Hulu, Manna Tengah dan Manna Hilir dengan luas DAS Manna sekitar 72.071,9 hektar (BPDAS Ketahun, 2011). Hulu DAS Manna berada pada daerah berbukit yang termasuk dalam wilayah administrasi Kabupaten Lahat Provinsi Sumatera Selatan, serta bagian hilir di Kabupaten Bengkulu Selatan dan langsung bermuara (outlet DAS) di Samudera Hindia.

\section{Pengambilan data}

Penelitian ini dilakukan dengan menggunakan metode penelitian survei tinjau, yaitu dengan cara mengumpulkan data dan informasi serta fakta-fakta dari gejala di lapangan dan analisis data spasial peta tematik menggunakan Sistem Informasi Geografi (SIG). Peta kedalaman tanah, peta kemiringan lahan dan erodibilitas tanah didapatkan dari data topografi tanah dan peta tanah. Sedangkan nilai erosivitas hujan didapatkan dari data curah hujan melalui perhitungan menggunakan rumus Bols. Peta penggunaan lahan dan tutupan lahan dihimpun dari data citra satelit. Peta kedalaman tanah, peta kemiringan lahan dan erodibilitas tanah didapatkan dari data topografi tanah dan peta tanah. Sedangkan nilai erosivitas hujan didapatkan dari data curah hujan melalui perhitungan menggunakan rumus Bols. Peta penggunaan lahan dan tutupan lahan dihimpun dari data citra satelit.

\section{Analisis data}

Data SIG yang diperoleh diolah untuk menentukan Bobot Erosi Lahan dan Tingkat Bahaya Erosi (TBE). Distribusi tingkat bahaya erosi di daerah penelitian diperoleh dengan menggunakan metode tumpang susun (overlaying) dan tumpang tindih (intersecting) antara peta tematik kedalaman tanah, peta tematik kemiringan lahan, dan peta tematik penggunaan lahan, serta bobot erosi.

Nilai dari indeks erosivitas hujan, indeks erodibilitas tanah, kemiringan lahan dan penggunaan lahan dianalisis dengan menggunakan rumus USLE sehingga mendapatkan nilai bobot erosi yang kemudian dianalisis melalui digitasi program ArcGIS Ver. 9.3 pada proyeksi UTM Zone 48S, sehingga terbentuklah Peta Tingkat Bahaya Erosi.

\section{Erosivitas Hujan}

Indeks erosivitas curah hujan ditentukan untuk setiap satuan lahan tersebut di atas. Data curah hujan yang digunakan adalah data dari pos hujan Batu Bandung milik BMKG Provinsi Bengkulu. Indeks erosivitas dihitung dengan menggunakan rumus Bols:

$$
\begin{aligned}
\mathrm{R}_{\mathrm{m}}= & 6,119 \times\left(\operatorname{Rain}_{\mathrm{m}}{ }^{1,21} \mathrm{x}(\text { Days })_{\mathrm{m}}{ }^{0,47} \mathrm{x}\right. \\
& (\operatorname{Max} \mathrm{P})_{\mathrm{m}}
\end{aligned}
$$

Dimana :

$$
\begin{aligned}
& \mathrm{R}_{\mathrm{m}}=\begin{array}{l}
\text { erosivitas curah hujan } \\
\text { bulanan rata-rata }\left(\mathrm{EI}_{30}\right)
\end{array} \\
& (\text { Rain })_{\mathrm{m}}=\begin{array}{l}
\text { jumlah curah hujan bulanan } \\
\text { rata-rata dalam cm }
\end{array} \\
& (\text { Days })_{\mathrm{m}}=\begin{array}{l}
\text { jumlah hari hujan bulanan } \\
\text { rata-rata pada bulan tertentu }
\end{array} \\
& (\text { Max } \mathrm{P})_{\mathrm{m}}=\quad \begin{array}{l}
\text { curah hujan harian rata-rata }
\end{array}
\end{aligned}
$$


maksimal pada bulan tertentu dalam $\mathrm{cm}$

dan $R={ }_{m=1}^{12}\left(R_{m}\right)$

dimana:

$\mathrm{R}=$ erosivitas curah hujan tahunan rata-rata

$=$ jumlah $\mathrm{R}_{\mathrm{m}}$ selama 12 bulan

\section{Erodibilitas Tanah}

Indeks erodibilitas tanah ini ditentukan untuk tiap satuan lahan. Indeks ini memerlukan data ukuran partikel tanah, \% bahan organik, struktur tanah dan permeabilitas tanah. Data tersebut didapat dari Peta Satuan Lahan dan Tanah Lembar 0912 Balitanak Bogor 1992 dengan melakukan analisis laboratorium contohcontoh tanah yang diambil di setiap satuan lahan. Nilai $\mathrm{K}$ diperoleh dengan menggunakan nomograf untuk menentukan erodibilitas tanah (Wischmeier et al, 1971 dalam Rahim, 2003).

Sifat-sifattanah yangmenentukan besarnya nilai $\mathrm{K}$ berdasarkan nomograftersebut adalah (1) persen kandungandebudanpasirhalus,(2)persenkan dunganpasir,(3)persenkandunganbahan organik,(4) (struktur dan tekstur batuan), dan relief permukaan batuan.

\section{Bahaya Erosi}

Bahaya Erosi dapat diketahui dengan cara menghitung jumlah tanah yang hilang pada unit lahan menggunakan rumus USLE, yaitu:

\section{$A=R \times K \times L S \times C \times P$}

Dimana :

$\mathrm{A}=$ jumlah tanah hilang (ton/ha/tahun)

$\mathrm{R}=$ erosivitas curah hujan tahunan rata-rata (biasanya dinyatakan sebagai energi dampak curah hujan (MJ/ha) x Intensitas hujan maksimal selama 30 menit $(\mathrm{mm} / \mathrm{jam})$

$\mathrm{K}=$ indeks erodibilitas tanah (ton $\mathrm{x}$ ha $\mathrm{x}$ jam) dibagi oleh (ha $\mathrm{x}$ mega joule $\mathrm{x} \mathrm{mm}$ )

$\mathrm{LS}=$ indeks panjang dan kemiringan lereng

$\mathrm{C}=$ indeks pengelolaan tanaman

$\mathrm{P}=$ indeks upaya konservasi tanah
Selanjutnya untuk mengetahui penyebaran setiap kelas bahaya erosi, dilakukan pengelompokan dan analisis penyebarannya pada setiap unit. Setiap kelas bahaya erosi mengacu pada Pedoman Penyusunan Rencana Teknik Rehabilitasi Hutan dan Lahan Daerah Aliran Sungai (RTkRHL-DAS). Kementerian Kehutanan (2009), yaitu:

Kelas bahaya erosi I SR: Kehilangan tanah $<15$ ton/ha/thn

Kelas bahaya erosi II R: Kehilangan tanah 15-60 ton/ha/thn

Kelas bahaya erosi III S: Kehilangan tanah 60-180 ton/ha/thn

Kelas bahaya erosi IV B: Kehilangan tanah 180-480 ton/ha/thn

Kelas bahaya erosi V B: Kehilangan tanah $>480$ ton/ha/thn

Tingkat Bahaya Erosi

Perkiraan erosi tahunan rata-rata (diperoleh dari USLE) dan kedalaman tanah (dari Peta Tanah) dipertimbangkan untuk menentukan Tingkat Bahaya Erosi untuk setiap satuan lahan. Urutan kegiatan pengukuran TBE di DAS Manna adalah sebagai berikut:

1. Mempersiapkan peta unit lahan dan tanah sebagai satuan pemetaan TBE

2. Menghitung nilai/ jumlah tanah yang hilang setiap satuan pemetaan dengan mempertimbangkan kedalaman solum tanah.

Kelas Tingkat Bahaya Erosi diberikan pada tiap satuan lahan dengan menggunakan kriteria pada Tabel berikut:

\section{Kelas Tingkat Bahaya Erosi}

\begin{tabular}{|c|c|c|c|c|c|}
\hline \multirow{3}{*}{$\begin{array}{c}\text { Solum } \\
\text { Tanah } \\
(\mathrm{cm})\end{array}$} & \multicolumn{5}{|c|}{ Kelas Erosi } \\
\cline { 2 - 6 } & I & II & III & IV & V \\
\cline { 2 - 6 } & \multicolumn{5}{|c|}{ Erosi (ton/ha/tahunan $)$} \\
\cline { 2 - 6 } & \multirow{2}{*}{15} & $\begin{array}{c}15- \\
60\end{array}$ & $\begin{array}{c}60- \\
180\end{array}$ & $\begin{array}{c}180- \\
480\end{array}$ & \multicolumn{2}{|c|}{480} \\
\hline Dalam & SR & R & S & B & SB \\
$>90$ & 0 & I & II & III & IV \\
\hline Sedang & R & S & B & SB & SB \\
$60-90$ & I & II & III & IV & IV \\
\hline Dangkal & S & B & SB & SB & SB \\
$30-60$ & II & III & IV & IV & IV \\
\hline Sangat & B & SB & SB & SB & SB \\
Dangkal<30 & III & IV & IV & IV & IV \\
\hline
\end{tabular}




\section{HASIL DAN PEMAHASAN}

\section{Erosi}

Hasil dari perhitungan dari data dan rumus tersebut didapat nilai erosivitas untuk DAS Manna 58.545,22. Tingginya curah hujan tahunan di DAS Manna yaitu $3620 \mathrm{~mm} / \mathrm{th}$ menyebabkan nilai erosivitas yang tinggi pula. Jumlah curah hujan bulanan rata-rata, jumlah hari hujan bulanan rata-rata, curah hujan harian ratarata maksimal pada bulan tertentu, dan nilai erosivitas dapat dilihat pada tabel 1 .

Dari Tabel 1 terlihat bahwa nilai $\mathrm{R}$ bulanan rata-rata tertinggi terjadi pada bulan Oktober yaitu 14111, dengan curah hujan rata-rata bulanan $604 \mathrm{~mm}$, jumlah hari hujan rata-rata bulanan 21 hari dan curah hujan harian rata-rata bulanan 128 mm. Nilai erosivitas rata-rata bulanan terendah terjadi pada bulan mei yaitu 1135 , dangan curah hujan rata-rata bulanan 159,3 $\mathrm{mm}$, jumlah hari hujan rata-rata bulanan 9 hari dan curah hujan harian rata-rata bulanan $48 \mathrm{~mm}$.

Pada bulan Agustus, September, Oktober, November, dan Desember, curah hujan rata-rata bulanan berturut-turut adalah $40 \mathrm{~mm}, 460,5 \mathrm{~mm}, 604 \mathrm{~mm} \mathrm{425,7}$ $\mathrm{mm}$ dan 425,7 $\mathrm{mm}$. Nilai-nilai tersebut menggambarkan bahwa pada bulan-bulan tersebut terjadi musim hujan. Seiring tingginya curah hujan pada bulaun-bulan tersebut, nilai erosivitas juga relatif lebih tinggi dibandingkan dengan bulan-bulan lainnya.

Indeks erodibilitas tanah ini ditentukan untuk tiap satuan lahan berdasarkan Peta Satuan Lahan dan Tanah keluaran Balai Penelitian Tanah dan Agroklimat lembar 0911 skala 1:250.000 tahun 1992. Indeks ini memerlukan data ukuran partikel tanah, \% bahan organik, struktur tanah dan permeabilitas tanah yang didapat dari analisis laboratorium contoh-contoh tanah yang diambil di setiap satuan lahan. Nilai $\mathrm{K}$ diperoleh dengan menggunakan nomograf untuk menentukan erodibilitas tanah (Wischmeier et al, 1971 dalam Rahim, 2003).

Sifat-sifat tanah yangmenentukan besarnya nilai $\mathrm{K}$ berdasarkan nomograf tersebut adalah persen kandungan debu dan pasir halus, persen kandungan pasir, persen kandungan bahan organik, struktur tanah, dan permeabilitas tanah. Karakteristik tanah

Tabel 1. Hasil perhitungan nilai erosivitas

\begin{tabular}{lcccc}
\hline \multicolumn{1}{c}{ Bulan } & $\begin{array}{c}\text { CH } \\
\text { Bulanan } \\
\text { Rerata } \\
\left.(\mathrm{cm})^{*}\right)\end{array}$ & $\begin{array}{c}\mathrm{HH} \\
\text { Bulanan } \\
\text { rerata*) }\end{array}$ & $\begin{array}{c}\text { CH } \\
\text { harian } \\
\text { rerata } \\
\text { maks } \\
\left.(\mathrm{cm})^{*}\right)\end{array}$ & $\begin{array}{c}\text { Erosivitas } \\
\left.(\mathrm{R}))^{* *}\right)\end{array}$ \\
\hline Januari & 3148 & 16 & 5,5 & 3148 \\
Februari & 3649 & 15 & 6,4 & 3649 \\
Maret & 2548 & 10 & 7,8 & 2548 \\
April & 1411 & 10 & 5,1 & 1411 \\
Mei & 1135 & 9 & 4,8 & 1135 \\
Juni & 2728 & 11 & 8,4 & 2728 \\
Juli & 3926 & 10 & 10,1 & 3926 \\
Agustus & 5939 & 12 & 10,5 & 5939 \\
September & 7668 & 17 & 9,3 & 7668 \\
Oktober & 14111 & 21 & 12,8 & 14111 \\
November & 6141 & 18 & 6,7 & 6141 \\
Desember & 6141 & 18 & 6,7 & 6141 \\
& & & TOTAL & $58.545,22$ \\
\hline Keterangan & & & &
\end{tabular}

Keterangan:

CH=curah hujan, $H H=$ hari hujan

*) Data pos hujan Batu Bandung BMKG Provinsi Bengkulu

**) Hasil perhitungan dengan rumus bols 
tersebut diyakini sangat berpengaruh terhadap erosi.

Wilayah DAS Manna sebagian besar berupa tanah mineral masam dan tanah tanah alluvial. Pada tingkat klasifikasi ordo menurut klasifikasi USDA, wilayah DAS Manna didominasi oleh tanah Inseptisol dan Ultisol. Jenis tanah entisol hanya terdapat sebagian kecil saja. Hampir sekitar 71,4\% wilayah DAS Manna berupa tanah inseptisol, terutama dari great group asosiasi Dystropepts. Pada umumnya di
DAS Manna, ordo inseptisol sangat dominan, dengan luas sebaran mencapai lebih kurang 87,2\%.

Berdasarkan hasil analisis laboratorium beberapa contoh tanah yang mewakili setiap unit lahan pada Peta tanah dan satuan lahan lembar 0911, dan dengan menggunakan monograf penentuan erodibilitas tanah, maka indeks erodibilitas untuk masing-masing satuan lahan di DAS Manna dapat dilihat pada tabel 2.

Dari Tabel 2 terlihat bahwa unit lahan

Tabel 2. Hasil perhitungan Indeks Erodibilitas tanah (K)

\begin{tabular}{|c|c|c|c|c|c|c|c|c|}
\hline \multirow{2}{*}{$\begin{array}{c}\text { UNIT } \\
\text { LAHAN }\end{array}$} & \multirow{2}{*}{$\begin{array}{c}\text { C- } \\
\text { orgnik }\end{array}$} & \multirow[t]{2}{*}{ K-sat } & \multicolumn{3}{|c|}{ Tekstur } & \multirow[t]{2}{*}{ Struktur } & \multirow[t]{2}{*}{$\mathrm{K}$} & \multirow[t]{2}{*}{ Luas (Ha) } \\
\hline & & & Pasir & Debu & Liat & & & \\
\hline Af.1.2.1 & 1,06 & $\mathrm{tt}$ & 55,7 & 18,34 & 23,89 & Granular halus & 0.26 & $1.056,2$ \\
\hline Af.1.2.2 & 1,16 & 65,10 & 57,26 & 25,07 & 17,67 & Granular halus & 0,26 & 169,5 \\
\hline Af.4.1.1 & 0,81 & SL & 74,34 & 12,19 & 13,47 & Granular kasar & 0,27 & $1.144,9$ \\
\hline $\mathrm{Au} .2 .2 .1$ & 2,91 & 0,80 & 86,26 & 6,34 & 7,40 & $\begin{array}{l}\text { Gumpal, lempeng, } \\
\text { pejal }\end{array}$ & 0,27 & $2.583,4$ \\
\hline Bfq.1.1 & 2,14 & 6,42 & 79,77 & 9,50 & 10,73 & Granular halus & 0,2 & 182,2 \\
\hline Bfq. 1.2 & 1,10 & 8,59 & 75,23 & 7,53 & 17,24 & Granular halus & 0,2 & $2.345,2$ \\
\hline Hf.1.2.2 & 2,20 & 1,31 & 63,59 & 14,29 & 22,12 & Granular kasar & 0,27 & $2.405,1$ \\
\hline Hf.2.2.2 & 2,61 & 2,04 & 70,78 & 11,85 & 17,37 & Granular kasar & 0,22 & $3.707,5$ \\
\hline Hf.2.3.3 & 2,04 & 10,88 & 55,93 & 16,09 & 27,98 & $\begin{array}{l}\text { Gumpal, lempeng, } \\
\text { pejal }\end{array}$ & 0,32 & 289,1 \\
\hline Hq.2.2.2 & 2,69 & 7,27 & 66,06 & 14,17 & 19,77 & Granular halus & 0,2 & $4.844,0$ \\
\hline Мa.2.2.2 & 2,95 & 12,53 & 68,14 & 13,15 & 18,71 & Granular halus & 0,14 & $8.296,8$ \\
\hline Ма.2.3.3 & 2,1 & 13,99 & 56,21 & 25,70 & 18,09 & $\begin{array}{l}\text { Gumpal, lempeng, } \\
\text { pejal }\end{array}$ & 0,3 & $1.306,0$ \\
\hline $\begin{array}{l}\text { Mab.2.2. } \\
3\end{array}$ & - & - & - & - & - & - & $0,1 *$ & $5.950,8$ \\
\hline Mg.2.3.3 & 3,90 & $\mathrm{tt}$ & 86,12 & 6,40 & 7,48 & Granular halus & 0,05 & $7.087,1$ \\
\hline Mq.2.2.2 & 4,31 & 3,48 & 74,96 & 10,87 & 14,17 & Granular halus & 0,08 & $4.898,5$ \\
\hline Mq.2.3.3 & 2,71 & 0,22 & 81,30 & 11,90 & 6,80 & Granular halus & 0,18 & $5.145,8$ \\
\hline Pf.5.2 & 3,05 & 2,82 & 72,46 & 12,05 & 15,49 & Granular halus & 0,15 & $1.515,3$ \\
\hline Pf.8.2 & 2,26 & SL & 57,18 & 20,77 & 22,05 & Granular halus & 0,32 & 260,5 \\
\hline Tf.2.1 & 1,73 & 3,69 & 69,20 & 17,93 & 12,87 & Granular halus & 0,2 & 356,2 \\
\hline Tf.3.2 & 2,03 & 4,25 & 66,33 & 16,20 & 17,47 & Granular halus & 0,2 & $1.710,8$ \\
\hline $\begin{array}{l}\text { Vab.1.2. } \\
3\end{array}$ & - & - & - & - & - & - & $0,1^{*}$ & $1.380,7$ \\
\hline $\begin{array}{l}\text { Vab.1.3. } \\
3\end{array}$ & - & - & - & - & - & - & $\begin{array}{r}0.1^{*} \\
\text { ) }\end{array}$ & $2.360,1$ \\
\hline $\begin{array}{l}\text { Vab.1.4. } \\
2\end{array}$ & - & - & - & - & & - & $\begin{array}{r}0.1^{*} \\
\text { ) }\end{array}$ & $5.361,7$ \\
\hline $\begin{array}{l}\text { Vab.2.10 } \\
.3\end{array}$ & - & - & - & - & - & - & $0.1 *$ & $2.731,5$ \\
\hline $\begin{array}{l}\text { Vab.2.11 } \\
.4\end{array}$ & - & - & - & - & 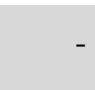 & - & $\begin{array}{r}0.1^{*} \\
\text { ) }\end{array}$ & $4.919,8$ \\
\hline X.1 & - & - & - & - & - & & $0.1^{*}$ & 63,2 \\
\hline & & & & & & & TOTAL & $72.071,9$ \\
\hline
\end{tabular}


yang memiliki areal terluas adalah $\mathrm{Ma}$ 2.2.2 dengan luas 8296,8 Ha dengan nilai indeks erodibilitas $(\mathrm{K})$ adalah 0,1 . Unit lahan dengan kode Ma 2.2.2. menurut Peta tanah dan satuan lahan lembar 0911 adalah unit lahan dengan jenis tanah berupa asosiasi great group Dystropept / Dystrandept.

Faktor topografi merupakan faktor yang sangat berpengaruh terhadap besarnya erosi. Nilai faktor panjang dan kemiringan lereng (LS) dapat ditentukan berdasarkan Peta Kemiringan Lahan saja dengan mengikuti ketentuan kelas kemiringannya. Gambaran kemiringan lahan di DAS Manna berikut luas arealnya untuk tiap kategori dapat dilihat padaTabel 3 .

Dari Tabel 3 terlihat bahwa sebagian besar wilayah DAS Manna berada pada kategori datar (0-8\%) dengan luas 20.589,6 $\mathrm{Ha}$ atau sekitar 28,6\%. Areal dengan kategori landai (8-15\%) seluas 13.833,3 Ha atau 19,2\%, areal dengan kategori agak curam (15-25\%) adalah 17.507,2 Ha atau
24,3\%. Untuk kategori kemiringan curam $(25-45 \%)$ dan sangat Curam (>45\%), luasnya berturut turut adalah $17.507,12 \mathrm{Ha}$ $(24,3 \%)$ dan $2.427,7 \mathrm{Ha} \quad(3,4 \%)$. Sedangkan hasil konversi kemiringan lahan kedalam nilai LS dapat dilihat pada Tabel 4.

Nilai C menunjukkan angka perbandingan yang berhubungan dengan tanah hilang tahunan pada areal yang bervegetasi dengan areal yang sama jika areal tersebut kosong dan ditanami secara teratur. Semakin baik perlindungan permukaan tanah oleh tanaman pangan/vegetasi semakin rendah tingkat erosi. Nilai faktor $C$ berkisar antara 0,001 pada hutan tak terganggu hingga 1,0 pada tanah kosong. Berdasarkan data tutupan lahan hasil interpretasi citra satelit, maka penentuan nilai $\mathrm{C}$ didasarkan pada kemiripan tutupan lahan hasil interpretasi citra satelit dengan kriteria penentuan nilai $\mathrm{C}$ dapat dilihat pada tabel 5 .

Tutupan lahan memainkan peranan

\section{Tabel 3. Relief DAS Manna berdasarkan Luas Kemiringan Lahan}

\begin{tabular}{|c|c|c|c|}
\hline No. & Kelas Kemiringan & Luas $(\mathrm{Ha})$ & Luas (\%) \\
\hline 1 & Datar $(0-8 \%)$ & 20589.6 & 28.6 \\
\hline 2 & Landai $(8-15 \%)$ & 13833.3 & 19.2 \\
\hline 3 & Agak Curam(15-25\%) & 17714.3 & 24.6 \\
\hline 4 & Curam (25-45\%) & 17507.2 & 24.3 \\
\hline \multirow[t]{2}{*}{5} & Sangat Curam $(>45 \%)$ & 2427.7 & 3.4 \\
\hline & & 72071.9 & 100 \\
\hline
\end{tabular}

Sumber Data :

1. Peta DAS Prop. Bengkulu, BP DAS Bengkulu

2. Peta Rupa Bumi Indonesia

3. Hasil Analisis Menggunakan Program ArcGIS ver 10 pada Proyeksi UTM Zone $48 S$

Tabel 4. Nilai LS di wilayah DAS Manna

\begin{tabular}{clrrr}
\hline No. & Kelas Kemiringan & LS & Luas (Ha) & \multicolumn{1}{c}{$\begin{array}{c}\text { Luas } \\
(\%)\end{array}$} \\
\hline 1 & Datar $(0-8 \%)$ & 0,25 & $20.589,6$ & 28,6 \\
2 & Landai $(8-15 \%)$ & 1,2 & $13.833,3$ & 19,2 \\
3 & Agak Curam $(15-25 \%)$ & 4,25 & $17.714,3$ & 24,6 \\
4 & Curam $(25-45 \%)$ & 9,5 & $17.507,2$ & 24,3 \\
5 & Sangat Curam $(>45 \%)$ & 12 & $2.427,7$ & 3,4 \\
\hline & & TOTAL & $\mathbf{7 2 . 0 7 1 , 9}$ & $\mathbf{1 0 0}$ \\
\hline
\end{tabular}


Tabel 5. Nilai C dan luasannya

\begin{tabular}{ccc}
\hline Nilai C & Luas $(\mathrm{Ha})$ & Luas $(\%)$ \\
\hline 0.001 & 9419.9 & 13.1 \\
0.01 & 18054.8 & 25.1 \\
0.1 & 3229.0 & 4.5 \\
0.3 & 31880.4 & 44.2 \\
0.5 & 7054.7 & 9.8 \\
0.6 & 1446.5 & 2.0 \\
0.95 & 37.8 & 0.1 \\
1 & 948.9 & 1.3 \\
\hline TOTAL & 72071.9 & 100
\end{tabular}

Sumber:

1. Peta tutupan lahan Provinsi Bengkulu,

2. Hasil Analisis Menggunakan Program ArcGIS ver 10 pada Proyeksi UTM Zone $48 S$

penting terhadap laju erosi tanah. Menurut Arsyad (2000), vegetasi memiliki peranan dalam aliran permukaan dan erosi yaitu: intersepsi hujan oleh tajuk, mengurangi kecepatan aliran permukaan dan daya rusak air, peranan akar dan kegiatankegiatan biologi lainnya, pengaruhnya terhadap stabilitas struktur dan porositas tanah, dan peran transpirasi dalam penyerapan air.

Berdasarkan tabel tersebut terlihat bahwa daerah yang paling luas adalah daerah dengan nilai $\mathrm{C}$ 0,3 atau dengan tutupan lahan kebun campur yaitu seluas $31.880,4 \mathrm{Ha}$ atau 44,2 \%. Wilayah dengan tutupan lahan hutan (nilai C 0,001) dan belukar tua (nilai $\mathrm{C} 0,01$ ), terlihat masih cukup luas, yaitu beturut-turut $9.419,9 \mathrm{Ha}$ $(13,1 \%)$ dan $18.054,8 \mathrm{Ha}(25,1 \%)$.

Sedangkan untuk faktor upaya konservasi, data yang ada tentang upayaupaya konservasi di wilayah DAS Manna sangat terbatas bahkan dapat dikatakan tidak tersedia. Berdasarkan penelusuran yang dilakukan di wilayah DAS Manna, tidak ditemukan adanya upaya konservasi tanah yang sistematis yang dilakukan oleh penduduk setempat. Sehingga penulis mengambil asumsi bahwa nilai $\mathrm{P}$ untuk seluruh wilayah DAS Manna adalah 1.

Perhitungan erosi aktual (nilai A) dengan menggunakan metode USLE, dilakukan dengan bantuan fungsi-fungsi dari aplikasi sistem informasi geografi (SIG). Besaran-besaran pendukung yang selain data numerik, tetapi juga merupakan data spasial seperti erosivitas (R), indeks erodibilitas tanah $(\mathrm{K})$, indeks panjang dan kemiringan lereng (LS), indeks pengelolaan tanaman (C), dan indeks perlakuan upaya konservasi $(\mathrm{P})$. Besaranbesaran tersebut selain dihitung secara numerik dengan formula USLE, juga dilakukan fungsi-fungsi SIG yaitu tumpang susun (overlay) seperti intersect. Nilai A yang diperoleh dari keseluruhan proses tersebut di atas adalah berkisar antara 1,4666.741,5 ton/ha/tahun. Tabel 6 menunjukkan gambaran TBE di DAS Manna berdasarkan hasil perhitungan dan overlay SIG

Berdasarkan Tabel 6 terlihat bahwa sebagian besar wilayah DAS Manna berada pada kategori TBE sangat berat (>480 ton/ha/th) yaitu seluas 46.204,5 atau $64,1 \%$ dari total luasan DAS Manna, kategori Berat (180-480 ton/ha/th) seluas $10.399,8 \mathrm{Ha}$ atau $14,4 \%$ dari total luasan DAS Manna, sedangkan wilayah dengan dengan kategori Sedang (60-180 ton/ha/th) seluas $6.393,5 \mathrm{Ha}$ atau $8,9 \%$ dan sangat rendah $(<15$ ton/ha/th) hanya seluas 1.533,2 $\mathrm{Ha}$ atau 2,1 \%. Hasil ini menunjukkan bahwa wilayah DAS Manna dapat digolongkan sebagai DAS yang kritis bila didasarkan pada potensi erosi yang 
ISSN:

Tabel 6. Tingkat bahaya erosi di DAS Manna

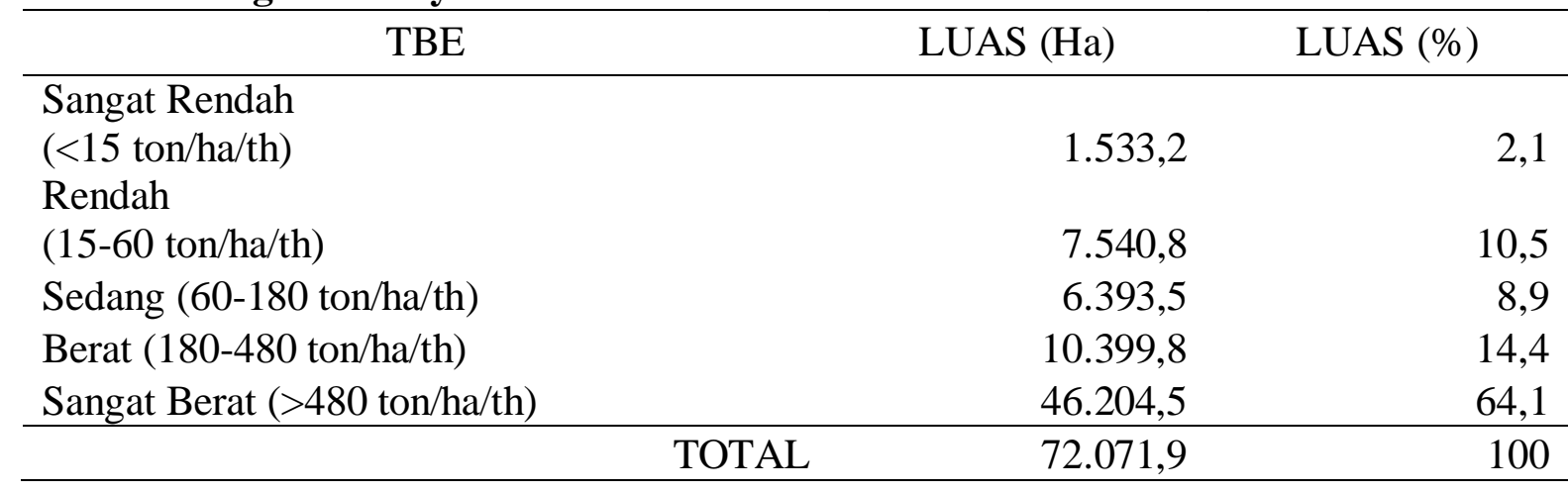

mencapai lebih dari $64 \%$ dari total luasan DAS Manna.

Dari hasil perhitungan TBE dapat diketahui bahwa ancaman degradasi lahan di DAS Manna sangat besar, sehingga DAS Manna dapat digolongkan kedalam DAS Kritis.

Luasnya wilayah DAS Manna yang memiliki TBE Berat (180-480 ton/ha/th) dan Sangat Berat (>480 ton/ha/th) disebabkan oleh faktor-faktor seperti erosivitas, erodibilitas tanah, kemiringan dan panjang lereng, serta pengelolaan tanaman, secara umum memiliki nilai yang relatif tinggi. Dalam hal erosivitas, DAS Manna memiliki curah hujan yang relatif tinggi (> $3500 \mathrm{~mm} /$ tahun), sehingga sangat besar pengaruhnya terhadap TBE. Selain itu, luasnya areal DAS Manna yang memiliki TBE berat hingga sangat berat, juga ditunjang oleh faktor kemiringan lahan di bentang alam yang sebagian besar berada pada kelas agak curam, curam, dan sangat curam. Faktor tanah juga ikut memberikan pengaruh signifikan, dimana DAS Manna didominasi oleh tanah-tanah yang peka erosi, yaitu Ultisol dan Inceptisol.

Bila ditinjau lebih jauh untuk masingmasing Sub DAS, maka hasil perhitungan TBE dapat dilihat pada Tabel 7. Dari tabel tersebut terlihat bahwa kategori TBE sangat berat $(>480$ ton/ha/th) terdapat paling luas pada Sub DAS Manna Hulu dengan luas $31.471,4 \mathrm{Ha}$ atau $43,7 \%$ dengan nilai potensi mulai dari berat seluas $7.719,3 \mathrm{Ha}$ atau $10,7 \%$ dan sangat berat
32.862,9 Ha atau 45,6 \% . Hal ini dikarenakan bentang alam pada Manna hulu yang berbukit-bukit sehingga mengakibatkan tingginya nilai LS.

Namun bila ditelaah lebih jauh, maka sebenarnya Sub DAS Manna hilir adalah Sub DAS yang paling tinggi potensi tingkat bahaya erosinya, dimana sekitar 78,2 \% (6.892,5 Ha) dari seluruh wilayah Sub DAS Manna Hilir berada pada kategori Sangat Berat ( $>480$ ton/ha/th) $6.892,5 \mathrm{Ha}$ atau $9,6 \%$, Berat $(180-480$ ton/ha/th) seluas $1.443,1 \mathrm{Ha}$ atau $2 \%$. Wilayah di Sub DAS Manna Hilir yang berada pada kategori rendah dan sedang berturut-turut hanya $4.9 \%$ dan $0,5 \%$. Tidak terdapat areal di Sub DAS Manna Hilir yang berada pada kategori TBE sangat rendah $(<15$ ton/ha/th).

Sedangkan untuk Sub DAS Manna Tengah, bila analisa hanya kita batasi pada sub DAS saja, maka areal yang berada pada kategori sangat berat juga paling luas, yaitu sekitar 50,3 \% $(6.495,2 \mathrm{Ha})$ dari keseluruhan wilayah Sub DAS Manna tengah. Wilayah di Sub DAS Manna Tengah yang berada pada kategori berat, sedang, rendah, dan sangat rendah, presentasenya berturut-turut adalah 9,7\% $(1.258,3 \mathrm{Ha}), 12,3 \%(1.587,6), 23,0 \%$ $(2.964,9 \mathrm{Ha})$, dan $4,7 \%(607,4 \mathrm{Ha})$.

Hasil yang relatif sama juga terjadi pada sub DAS Manna hulu, dimana sebagian besar wilayahnya berada pada kategori sangat berat, yaitu seluas $32.862,9$ atau $65,3 \%$ dari keseluruhan luas Sub DAS Manna hulu. Sedangkan TBE untuk 
Tabel 7. Tingkat bahaya erosi pada masing-masing Sub DAS

\begin{tabular}{clrr}
\hline Sub DAS & \multicolumn{1}{c}{ TBE } & LUAS $(\mathrm{Ha})$ & LUAS (\%) \\
\hline Manna Hulu & Sangat Rendah $(<15$ ton/ha/th) & 916,3 & 1,3 \\
& Rendah $(15-60$ ton/ha/th) & $4.091,0$ & 5,7 \\
& Sedang $(60-180$ ton/ha/th) & $4.759,4$ & 6,6 \\
& Berat $(180-480$ ton/ha/th) & $7.719,3$ & 10,7 \\
& Sangat Berat $(>480$ ton/ha/th) & $32.862,9$ & 45,6 \\
Manna Tengah & 607,4 & 0,8 \\
& Sangat Rendah $(<15$ ton/ha/th) & $2.964,9$ & 4,1 \\
& Rendah $(15-60$ ton/ha/th) & $1.587,6$ & 2,2 \\
& Sedang $(60-180$ ton/ha/th) & $1.258,3$ & 1,7 \\
& Berat $(180-480$ ton/ha/th) & $6.495,2$ & 9,0 \\
& Sangat Berat $(>480$ ton/ha/th) & 429,9 & 0,6 \\
Manna Hilir & Rendah $(15-60$ ton/ha/th) & 44,1 & 0,1 \\
& Sedang $(60-180$ ton/ha/th) & $1.443,1$ & 2,0 \\
& Berat $(180-480$ ton/ha/th) & $6.892,5$ & 9,6 \\
\hline & Sangat Berat $(>480$ ton/ha/th) & $72.071,9$ & 100 \\
\hline
\end{tabular}

kategori berat, terdapat 15,3\% areal di sub DAS Manna Hulu atau sekitar 7.719,3Ha. Untuk kategori sedang, rendah dan sangat rendah, presentasenya berturut-turut adalah $9,5 \%(4.759,4 \mathrm{Ha}), 8,1 \%(4.091,0 \mathrm{Ha})$, dan $1,8 \%(916,3 \mathrm{Ha})$.

\section{KESIMPULAN}

Sebagian besar wilayah di DAS Manna berada pada kategori tingkat bahaya erosi (TBE) Sangat Berat ( $>480$ ton/ha/th) yaitu seluas 31.471,4 Ha (43,7 \%). Sub DAS Manna Hulu merupakan Sub DAS yang memiliki luasan TBE paling luas yaitu sebesar $32.862,9 \mathrm{Ha}(45,6 \%)$ dari total luasan DAS Manna. Sedangkan bila dianalisa pada tiap Sub DAS, maka Sub DAS Manna Hilir adalah Sub DAS yang paling luas terdapat TBE dengan kategori sangat berat, yaitu seluas 76,5 \% (6.882,9 Ha) dari luas keseluruhan Sub DAS Manna Hilir. Hasil tersebut sudah cukup menggambarkan bahwa DAS Manna dapat digolongkan kedalam DAS kritis berdasarkan potensi tingkat bahaya erosinya.

\section{DAFTAR PUSTAKA}

Alibasyah, R. 1996. Pengolahan Tanah Konservasi Untuk Menunjang Pertanian Berkelanjutan Pada Lahan Kering. Program Pascasarjana Unpad, bandung.

Anonim. 2009. Tata Cara Penyusunan Rencana Teknik Rehabilitasi Hutan Dan Lahan Daerah Aliran Sungai (RTkRHL-DAS). Peraturan Menteri Kehutanan RI. Nomor: P.32/MENHUT-II/2009.

Anonim, 1998. A guide for Land Rehabilitation and Soil Conservation of Watershed. Forestry Department of The Republic of Indonesia. Jakarta.

Arsyad, S. 1983. Konservasi Tanah dan Air. IPB Press, Bogor

Arsyad, S. 2000. Konservasi Tanah dan Air. IPB Press, Bogor. Cetakan kedua

Asdak, C. 2004. Hidrologi dan Pengelolaan Daerah Aliran Sungai. Gadjah Mada University Press. Yogyakarta.

As-syakur, AR. 2003. Prediksi Erosi Dengan Menggunakan Metode 
USLED dan Sistem Informasi Geogras (SIG) Berbasis Piksel Di Daerah Tangkapan Air Danau Buyan. PIT MAPIN XVII, Bandung 10-12-2008.

BPDAS Ketahun. 2011. Naskah Utama Inventarisasi Dan Identifikasi Karakteristik DAS Manna. Bengkulu.

BPDAS Ketahun. 2011. Rencana Pengelolaan DAS Terpadu DAS Bengkulu. Bengkulu.

Dangler, EW and SA. El-Swaify. 1976. Erosion Of Selected Hawaii Soils by simulated rainfall. Soil Sci. Soc. Am. J. 40:769-773.

Dariah, A, H. Subagyo, C. Tafakresnanto, dan S. Marwanto. 2004. Kepekaan Tanah Terhadap Erosi. Tidak dipublikasikan.

Dirjen RLPS. 2009. Peraturan Dirjend RLPS Nomor P.04/V-SET/2009 tentang Pedoman Monitoring dan Evaluasi Daerah Aliran Sungai.

Herawati, T.2010. Analisis Spasial Tingkat Bahaya Erosi Wilayah DAS Cisadane Kabupaten Bogor. J. Pen. Hutan dan Konservasi Alam. VII(4): 413-424.

Hidayat, MF dan E. Suharto. 2009. Model Pengelolaan Sub Daerah Aliran Sungai (DAS) Ketahun Hulu Berbasis Eko-Hidrologi Untuk Pengendalian Banjir dan Kekeringan di Kabupaten Lebong Tahun Kedua. Laporan Hibah Bersaing, LP UNIB, Bengkulu. Tidak dipublikasikan.

Lane, J.L. and J.J. Stane, 1983. Water Balance Calculations, Water Use Efficiency and Above Ground Net Production. Hydrology and Water
Resources in Arizona and Southwest. (13) : $27-34$.

Linsley, RK, MA. Kohler, JLH. Paulus, Hermawan. 1996. Hidrologi untuk insinyur (Edisi ketiga). Erlangga. Jakarta.

Londongsalu, DT. 2008. Analisis Pendugaan Erosi,Sedimentasi, dan Aliran Permukaan Menggunakan Model AGNPS Berbasis Sistem Informasi Geografis di Sub DAS Jeneberang Propinsi SulawesiSelatan. Skripsi Departemen Silvikultur Fahutan IPB (Tidak dipublikasikan)

Manan, S. 1985. Peranan Hidrologi Hutan Dalam Pengelolaan DAS. Dalam Prosiding Lokakarya Pengelolaan DAS Terpadu. Yogyakarta.

Muins, S. N. 1996. Kajian Hubungan Erodibilitas Tanah (Nilai K) dengan Karakteristik Tanah Kuantitatif. Lembaga Penelitian UNIB. Jakarta.

Priatna, SJ. 2001. Indeks Erodibilitas Dan Potensi Erosi Pada Areal Kebun Kopi Rakyat Dengan Umur Dan Lereng Yang Berbeda. J. I. Pertanian Indonesia 3(2):84-88.

Rahardi, B; E. Nurhayati; E. Purwanti; dan E. Suhartanto. 2008. Penilaian Tingkat Bahaya Erosi Dengan Menggunakan ArcView GIS. Tek. Dan Kejuruan 31(1):15-25.

Rahim, SE. 2003. Pengendalian Erosi Tanah Dalam Rangka Pelestarian Lingkungan Hidup. Bumi Aksara. Jakarta. 150 hlm.

Ramdan, H. 2004. Prinsip Dasar Pengelolaan Daerah Aliran Sungai. Lab. Ekologi Hutan Fahutuan Univ. Winaya Mukti. Bandung. 
INDEKS PENULIS

Volume 1 Nomor 1, Juni 2012

Enggar Apriyanto, 58

Puji Harsono, 58

Afdhal Redha, 58

Agus M.H.Putranto, 1

Agus Martono, 50

Bandi Hermawan, 29

Bandi Hermawan ${ }^{2}, 41$

Bieng Brata, 7, 35, 66

Dian Sari, 29

Dwinardi Apriyanto, 15

Edi Suharto, 75

Elvi Hayani, 1

Etmon Juliansyah, 50

Herwan, 41

, 66

Irda Hayani S, 75

M. Faiz Barchia, 29, 41, 75

M. Taufik, 66

Mubarakkan, 66

Puji Harsono, 1, 50

Rohidin, 7

Rohidin Mersyah, 35

Siti Zulaiha, 15

Suprapto, 15

Yeti Marleni, 35

Yogi Kosmanto, 7 